\title{
Brexit's Identity Politics and the Question of Subjectivity
}

Nikolay Mintchev and Henrietta L. Moore

(article published in Psychoanalysis, Culture \& Society, 2019)

\begin{abstract}
This article is about the socially divisive consequences of the UK's 2016 referendum on membership in the European Union. Rather than redressing the country's long-standing class divisions, the referendum has exacerbated them by fuelling negative stereotypes and mutual accusations between Leave and Remain supporters. Drawing on psychoanalytic theories of subjectivity, the article argues that support for Leave and Remain is structured by circulations of affect, fantasies of the good life, and psychic investments in different experiences of immigration, nationalism and social and economic inequality.
\end{abstract}

Keywords: affect; immigration; nationalism; inequality; ressentiment

In 2014, the political scientists Robert Ford and Matthew Goodwin published a book entitled Revolt on the Right. There, they presented a detailed account of the social, economic and political factors that drove support for Euroscepticism in the UK, as well as support for the United Kingdom Independence Party (UKIP) - a single-issue party determined to get the UK out of the European Union. In the final pages of the book, the authors explained that the political existence of UKIP and other Eurosceptics would face a significant threat if the UK was to hold a referendum on its membership in the EU. This, they argued, would happen regardless of the referendum's outcome: 
If the British public voted to remain in the European Union, it would reduce the potency of Euroscepticism, settling the debate over the EU, for the short term, at least. If UKIP politicians continued to agitate for exit, they would risk looking like out-of-touch obsessives [...]. On the other hand, if the British public did vote to leave the EU, which at the time of writing appears unlikely, UKIP would enjoy its great policy triumph - and the next day would find itself deprived of its reason for being. (pp. 286-287)

Looking at this passage in hindsight, it is clear that the situation was more complex than Ford and Goodwin's analysis anticipated. The UK held a referendum in 2016 in which a small majority of $51.9 \%$ opted to leave the EU, but the dust did not settle as predicted and Euroscepticism is far from losing its reason for being. While it is true that UKIP is a spent political force, the issue that it championed is the defining issue of the day. In fact, UKIP's former leader Nigel Farage and his newly established Brexit Party recently finished first in the UK's 2019 European Parliament Election, winning 30.5\% of the vote and 29 out of 73 seats. The debate about EU membership has not been resolved, and the social and political tensions which led to the referendum in the first place have not died down. In fact, if anything, the referendum has been more divisive than unifying, and instead of settling some of the tensions in a country with deep economic and social inequalities, it has only exacerbated them further.

Why has this happened and how can we make sense of it? What are the factors that sustain, reproduce and exacerbate this division? This article addresses these questions by drawing on psychoanalytic models of subjectivity. It argues that one of the key factors at work in the UK's post-referendum division is psychic investment in specific subject-positions of national and ethnic identity, socio-economic status, and political participation - investment in 
forms of being in the world and of relating to oneself and others as a particular type of subject marked by nationality, class and political representation.

Analyses in the social sciences have provided invaluable insight into a number of factors that influenced the referendum's outcome: the discourses used by the Leave and Remain campaigns; the economic inequalities that underpinned the voting pattern; and the multitude of social and economic concerns that correlated with people's decisions in the vote (e.g. Clarke et al., 2017, Clarke and Newman, 2017, Dorling, 2016, Goodwin and Heath, 2016, Hobolt, 2016). A psychoanalytic approach, however, can add to these analyses by drawing attention to the unconscious dimensions of social and political agency: the unconscious affects, fantasies and desires that animate people's actions, beyond the determinations of social and economic factors (see Frosh, 2018; Moore, 2007).

The Brexit divide is largely driven by subjective feelings of injustice in which immigration, a perceived loss of national sovereignty and growing income inequality are seen as benefiting some people at the expense of others. At the same time, however, it is also about different visions of prosperity. While some people hold a 'nation-centred' vision of prosperity in which better quality of life is delivered within a national framework that privileges its historically-established White British (and especially English) community, others believe in a more 'cosmopolitan' vision of diversity and interconnectedness (Delanty, 2017). These two visions are caught up in an affective deadlock of mutual ressentiment in which commitment to one's view amounts to a failure to accept, understand and empathise with the views of others. Attentiveness to this subjective dimension and the dynamics of affect and fantasy that underpin it is crucial for understanding identity in post-referendum Britain, as well as the reasons for which the referendum is exacerbating the country's divisions rather than redressing them. 


\section{Inequality, identity and the Brexit referendum}

Political analyses after the referendum have made clear that the profiles of Leave and Remain voters differed in age, education, ethnicity and economic status. The Leave demographic was on average older, less educated and predominantly White English and Welsh (Ashcroft, 2016; Goodwin and Heath, 2016). While the Leave vote was highest in England (53.38\%) and Wales (52.53\%), the Remain side saw stronger support in Scotland (62.00\%) and Northern Ireland (55.78\%). In this article, we specifically focus on England - the country with the highest number of both Remain and Leave votes - but we do acknowledge that each of the Union's four countries has a unique political, social and economic history, as well as a unique vision of national identity, that defines how people view the European Union. The Leave demographic was also on average less well-off economically, although, as the data clearly show, support for Leave and Remain does not map easily onto socio-economic categories. On the one hand, much of the support for Brexit came from White English working-class communities, whose economic and social status has undergone sustained decline over the past four decades. This is supported by both polling data (Ashcroft, 2016) and ethnographic case studies that show the extent to which Eurosceptic and populist support has been driven by economic desperation and disconnection from the overall prosperity of the country (Evans, 2017; Koch, 2017; McKenzie, 2017; Thorleiffson, 2016). On the other hand, Brexit cannot be seen as the deed of the working class because, although approximately two thirds of people in 'working-class' occupations C2 and D within the National Readership Survey Classification - voted to leave, the majority of Brexit supporters (59\%) were employed in 'middle-class' occupations (A, B and C1) (Hening and Dorling, 2016, p. 20). In other words, 'it was middle-class voters in Middle England areas that predominantly voted for Leave in the largest absolute numbers - the numbers that mattered' (Dorling and Tomlinson, 2019, p. 30). 
Despite their differences in economic status and occupation, however, one thing that middle-class Leave voters shared with working-class Leave supporters was a perception of personal economic decline and poverty. What mattered with respect to middle-class Brexit voters was not that they were poor, but rather that they felt poor - what mattered was 'a person's narrow feelings about his or her own financial situation' (Liberini et al., 2017, p. 4; see also Dorling and Tomlinson, 2019, p. 30). This is in contrast to Remain voters, who were on average better educated and thus had better employment opportunities, but who also felt more financially comfortable and lived in well-off areas, especially in multicultural urban centres.

The relationship between voting patterns and socio-economic factors intersects with another pattern which is primarily based on culture and identity as defined in relation to the nation state. As Gerard Delanty (2017) argues, the Brexit divide is an expression of a newly emerging social cleavage, not just within the UK but across Europe and elsewhere, between what he refers to as 'nationals' and 'cosmopolitans', or in other words between those who are 'nation-centred' and those who are positively engaged with 'wider horizons' beyond the nation state (p. 112; see also Hobolt, 2016, p. 1265):

On the one side, there are those whose lifeworld is defined by the national state and the traditional markers of class. On the other side, there are those whose lifeworld has been significantly shaped by wider horizons than those of the national culture and who, while having class positions, do not identify with class as such or with class-based lifestyles. (p. 116)

This point has also been suggested by Clarke and Newman (2017), who point out that 'Brexit was supported by [a] traditional(ist) middle class in the suburbs, small towns, and shires that remained resolutely "non-cosmopolitan" and were apparently consumed by immigration anxiety (despite such spaces not being occupied by many migrants)' (p. 106). Much like the economic explanation that points to a feeling of decline, this second understanding of Brexit 
as a cleavage between 'nationals' and 'cosmopolitans' is also based on a subjective experience of exclusion by those who supported Brexit. The conflict between different 'life-worlds' is closely related to the experience of economic decline and provides a narrative framework of cultural representations and values - particularly those related to the perils of immigration and the loss of national sovereignty to the EU - through which people interpret their economic circumstances and feelings of alienation.

Over the past three decades, the long-standing ethos of British (and especially English) nationalism has faced significant challenges. What we mean by nationalism here is not the violent, exclusionary nationalism of extreme-right groups, which have never been particularly strong in the UK; what we mean, instead, is the larger socio-political configuration in which one's worth as a citizen is affirmed on the basis of his or her commitment and contribution to the nation-state. This is a post-war ethos in which the welfare state and the equitable distribution of jobs and resources are seen as an expression of national solidarity following the huge sacrifices that working-class communities made during the war. It is also an ethos in which labour - and especially manual labour - is seen as the lifeblood that keeps the nation going.

The diversification of London and other urban centres, the arrival of multiple waves of migrants from all corners of the world and the continuing decline of industries that depend on a locally recruited labour force have challenged this ethos both economically and ideologically. Economically, industrial decline, welfare cuts and growing inequality have rendered people and places outside of main economic hubs inessential and dispensable. People who previously saw themselves as occupying the centre stage of the nation's economic life have ended up at the margins (Gest, 2016, 2018). Ideologically, the growing recognition of the value of diversity and openness at the expense of British nationalism has devalued the symbolic currency that once came with a legacy of sustained national commitment and sacrifice. Recognition, as well 
as economic opportunity, have become more closely linked to experience, knowledge and skills developed in different places and cultural contexts throughout the world, and progressively more detached from commitment to one's community and country. In other words, the nationcentred lifeworld that Delanty and others talk about has become minoritised and even provincialised - it is no longer at the centre of Britain's economy and culture. Imperial nostalgia plays an important role here as an envisaged solution to this economic and social change, which is why it has been so prominent in defining the political imagination of Leave supporters (Virdee and McGeever, 2018; Dorling and Tomlinson, 2019). The idea that Britain - imagined as White and Anglo-Saxon - could once again achieve international domination, while closing its borders to foreigners, represents a surge of economic affluence for those who see themselves as facing economic decline, as well as a return of White British nationalism as a central value of social and economic life.

Understanding the Brexit deadlock requires attentiveness to economic and cultural change, as well as an understanding of the psychic investments and relays of affect that sustain the current impasse. Within sociology, there is a long tradition of theoretical arguments about the relationship between the economic and cultural registers, particularly in relation to class identity. These debates have focused on specific patterns of behaviour - for example, those associated with dress, food, language and bodily appearance - that produce and reproduce a hierarchy of cultural stereotypes that are associated with, and in fact define, socio-economic classes. This notion of class as defined through culture is linked to another set of arguments about the way in which people inhabit and embody different subject-positions within an economically and symbolically unequal world. Class identity - as well as gender, sexuality and ethnicity/race - is socially constructed and historically contingent, but at the same time is inscribed and sedimented within the subject's body (Bourdieu, 1984; Biressi and Nunn, 2013; Skeggs, 1997, 2004). 
Psychoanalysis offers a useful counterpart to this theoretical edifice because it approaches the issue from the methodological starting point of psychic process and the relationship between the social and the psychic, rather than from the perspective of the social field. More concretely, a psychoanalytic approach, especially in its Kleinian/object relational variation, can bring into the foreground the dynamics and vicissitudes of affective attachment, as well as the range of mechanisms - such as splitting, projection and identification - that organise the subject's affective relationships to people, places and ideas. Furthermore, psychoanalysis in its Lacanian variation can allow us to articulate the limits of power and subjectification. The subject is embedded within an economic and cultural context, but it is never fully determined by it. There is always a paradoxical kernel of both 'excess' and 'lack' within the subject that evades the grasp of power (see Moore, 2007; Mintchev, 2018). This is the ontological condition of agency, which can take the forms of repetition and reenactment as well as personal and social change. It enables the subject to think and act in ways that are irreducible to its context and to the logics of the economic, social and political status quo.

\section{Subjectivity and affect}

Understanding how and why the Brexit schism is entrenched in British society is a matter of addressing the narrative dimension of subject-formation as well as its object-relational and affective dimension (Mintchev, 2017, 2018). This requires a multi-layered analysis that draws on a number of strands of psychoanalytic theory. Within psychoanalysis there are different approaches to defining the human subject and its unconscious. While some theories emphasise the primacy of language and narrative, others prioritise the importance of instincts/drives, and yet others focus on the capacity for relationships as the most fundamental psychic feature (Moore, 2007, p. 63). Such 'pre-theoretical assumptions' define the ways in which theoretical and empirical analyses proceed and what they ultimately achieve. Our approach in this article 
is to draw on a variety of theories, but in doing so to address multiple key elements of subjectivity, including affects, relationships and fantasy structures. Subjectivity is always shaped by the social and political discourses which offer us the material for constructing an account of ourselves and others (Butler, 2005; Moore, 2011). It is formed through identifications with people in the external world, ranging from parents and caretakers to community leaders and distant others. But these people are always caught up in cultural narratives that contextualise them and give them meaning, and so identification is always, in one way or another, identification with cultural stories or stereotypes.

However, in addition to a prominent narrative dimension, subjectivity also has an object-relational counterpart, whereby encounters with, and relations to, oneself and others define psychic experience in a way that is irreducible to language and symbolic meaning. This object-relational aspect of subjectivity has been emphasised and elaborated in detail by Melanie Klein and a number of psychoanalytic and social theorists building on her work (e.g. Butler, 1998; Kristeva, 2001; Rose, 1993; Sedgwick, 2007). According to the Kleinian theoretical paradigm, the subject is constituted through a series of projections and introjections - or projective and introjective identifications, in Kleinian terms - with objects and people. These processes, which are mediated and shaped by the subject's libidinal and aggressive drives, form the basis of psychic life and the experience of anything from love and hate to anger, fear, remorse, envy and gratitude.

Klein's model of object-relating, as Eve Kosofsky Sedgwick (2007) argues, offers valuable insight for understanding social and political processes because of the way in which it theorises affect as volatile and susceptible to positive and negative feedback cycles. The concept of affect, as Sedgwick uses it and as we use it in this paper, is somewhat different from the classical psychoanalytic notion of the term (in fact, Klein herself did not write about her theory as a theory of affect as Sedgwick does). In classical psychoanalytic usage, affect refers 
to an emotional experience - anything from a general mood to a spurt of acute anxiety resulting from the release or 'discharge' of psychic energy (Laplanche and Pontalis, 1973, pp. 13-14). Affect, in this sense, is the 'discharge' of what Freud called cathexis (psychic investment).

The notion of affect as Sedgwick (2007) uses it retains this reference to manifest emotions - especially anxiety - but it also treats affect as something that can be circulated and 'exchanged' in one's relations to others (pp. 631-632). This latter aspect of affect resonates in some ways with the theoretical tradition rooted in the philosophy of Spinoza (1996) and its later development by Deleuze and Guattari (2004), among others. Affect, within the Spinozist and neo-Spinozist theoretical framework, does not refer to manifest emotional experiences, but to a multiplicity of intensities or energies that are 'immanent' within people and things. These intensities/energies are seen as the driving force of both animate and inanimate beings, and the internal cause of their transformation and interconnectedness. The subject is then theorised as an assemblage of circulating intensities and connections with other people and things (Braidotti, 1994, 2011).

As the ethnographic writing on Brexit suggests, one of the consequences of the referendum was to mobilise and consolidate bonds and relations among Leave and Remain supporters. For example, as Ana Balthazar's (2017) ethnography of Margate, England shows, the idea of Brexit garnered a logic of community-building based on a shared commitment to the symbols of British national identity, a nostalgia for the past and disillusionment with poor political representation and immigration into the country. One of Balthazar's fieldwork interlocutors - a retired woman volunteering in a charity shop - expressed this form of bonding very aptly, when she said that 'Everybody we know voted out. We are all singing from the same hymnbook here' (p. 220). What this woman meant was that all her friends and acquaintances in the town had the same discontents with the present and the same aspirations 
for Britain to change its political and economic trajectory. Brexit supporters in Margate also identified with a shared past of working-class hardship, even if they were financially comfortable and had good housing. This collective experience of past, present and future was mobilised by Brexit to strengthen the sense of identity and community among established residents, as well as newcomers to the area: 'Voting Brexit [...] generated relatedness among people who did not know each other before, who recently retired to the area, but who share collective working-class memories' (p. 223).

A similar mobilisation of relatedness was evident among Remain supporters, who also came together around a set of shared ideas and symbols of Europe, openness and cosmopolitanism. This is best exemplified by the marches against Brexit that took place in London (most notably in March 2017, June 2018 and March 2019), as well as the multiple proRemain activist groups and organisations that emerged in response to the referendum's outcome. As Gabriel Popham's (2017) study of post-referendum London shows, many Remain supporters experienced shock, disappointment and anxiety about Brexit because they associated it with economic disaster, xenophobia and racism. On the basis of these feelings, Remain supporters from across the country came together and took to London's streets. Popham recalls his experience of participating in one demonstration as follows:

[P]eople marched in Central London [...] to celebrate the sixtieth anniversary of the Treaty of Rome and to protest Brexit by showing the breadth of opposition from across the country. [...] As we shuffled down Pall Mall, flags of blue and yellow waving above our heads, people chanted Beethoven's Ode to Joy, the EU's official anthem. Many of us were carrying daffodils and irises, jointly mourning Brexit and those who had lost their lives at the Westminster bridge attack the previous week. (p. 31) 
Here, in line with the vignette of Brexit supporters in Margate, people are also 'singing from the same hymnbook' as a way of protesting against Brexit. They are coming together as a community united by common symbols, anxieties and aspirations, and in doing so they are building new affective attachments and commitments to each other and to their shared beliefs.

\section{Ressentiment}

The two subject positions of Leave and Remain are based not only on a sense of belonging to a community of shared values, but also on a sense of opposition to others along the lines of 'national' and 'cosmopolitan' lifeworlds. The 'other' of Brexiters is embodied by both immigrants coming to the UK and Remainers who represent the allegedly pro-immigration and pro-European ‘liberal elite’ (see Balthazar, 2017; Gest, 2016, 2018; Koch, 2017; Pitcher 2019). The 'others' of Remain supporters, in contrast, are the allegedly misguided Brexit voters who were either misled by the lies of populist politicians or voted on the basis of racism and xenophobia (see Popham, 2017, p. 31).

Psychoanalysis has long recognised that subjectivity is relational and that the subject is constituted through differentiation and opposition to others. This is now a truism in much of social theory writing. Less discussed, however, are the mechanisms, processes and vicissitudes of affect that constitute intra- and inter-subjective relations. Melanie Klein's model of the mind is particularly useful here because it offers the conceptual tools to capture the circulations of affect between people and within communities. Klein's understanding of the psychic economy - which marks a significant departure from Freud's model - reveals why social antagonisms can persist and escalate even when this is clearly not in the interest of those involved. While Freud maintained that the psyche constantly strives to minimise the excitation generated from both internal and external stimuli, Klein emphasised its propensity for generating feedback 
loops in which negativity is addressed by further negativity, resulting in a vicious cycle of aggression and reproach (Hinshelwood, 1991, pp. 282-283). This is complemented by similar cycles of positive affect in which affirmation of others like oneself produces a dynamic of belonging based on reciprocal validation of shared experience.

This mode of relating, according to Klein, depends on psychic 'splitting' both within the subject and between people. When splitting takes place, the libidinal drives and the aggressive drives are separated from one another so that the subject can experience something or someone as wholly good or wholly bad without nuance or ambivalence. The splitting of good and bad is a basic psychic mechanism that is available to all humans, but the extent to which it defines the subject's relationships to others depends on context and circumstances. As Klein explained (e.g. 1940, p. 345; 1955, pp. 138-139), internal and external experiences are always intertwined and responsive to one another, and so a polarised world of inequality and social division will be reflected accordingly in intrapsychic and interpsychic object-relations.

The problem, however, is that splitting and polarisation can trigger a chain of psychic events that takes a life of its own and creates a cycle of aggression and reproach towards some people, while simultaneously strengthening affirmation and belonging in relation to others. This occurs because the subject's experience of being victimised can lead to aggression towards the other as a response, which in turn triggers anticipation of reciprocation whereby the other retaliates once again. A feeling of being wronged or victimised leads to a desire to undermine the perpetrator, which in turn leads to anticipation of being wronged again in a seemingly perpetual feedback loop.

In her article on Klein's theory of affect, Sedgwick (2007) aptly draws a link between the vicious cycles described by Klein and the notion of ressentiment developed by Nietzsche (1967) that has been more recently elaborated by a number of theorists (e.g. Brown, 1993; Berlant, 2000 Berlant and Greenwald, 2012). Nietzsche's ressentiment, as Sedgwick (2007) 
describes it, is 'a self-propagating, near-universal psychology compounded of injury, rancor, envy, and self-righteous vindictiveness, fermented by a sense of disempowerment' (p. 635). Furthermore, it is 'a "chronic" form of resentment [...] [which] involves an actor's sense of unjust and undeserved deprivation or injury, which is attributed to the actions of another actor who is perceived to gain from this deprivation or injury' (Le Grand, 2015, p. 2). Ressentiment is thus a circular dynamic of injury, which is at once 'self-propagated' and 'attributed to the actions of another' (either rightly or wrongly) through projection/projective identification. This means that the configuration of self-other relations in the dynamics of ressentiment has an affective underpinning that keeps it locked in place, even in the face of arguments that challenge its justifications.

In the case of Brexit, rejection of the other and resentment towards him or her is supplemented with accusations that the other harbours resentment towards the self, leaving an oppositional deadlock with few possibilities for compromise or acknowledgement of a mutually beneficial middle ground. But what does this dynamic of ressentiment look like on the ground and how does it manifest itself? As Lisa McKenzie's ethnographic work in East London, Derbyshire and Nottinghamshire demonstrates, support for Brexit in these areas was motivated by a sense of being invisible, irrelevant, and even 'non-existent' for those who govern the country. McKenzie (2017) observes that, while the people she worked with were very disengaged and apathetic during the 2015 general election, their approach to the referendum on EU membership was different and more engaged. This was because they saw the referendum as an opportunity to be noticed and recognised through a vote that rejected and attacked what they saw as the power of the ruling elites. 'From their standpoint, the decision to vote leave was a way to kick back at an establishment that they felt let down by' (p. 205; see also Koch, 2017). 
However, at the same time as attacking the establishment, some of McKenzie's interlocutors also dismissed by default people who supported or campaigned for Remain. The following vignette from McKenzie's (2017) ethnography illustrates how this kind of dismissal leads to a breakdown of dialogue and a cycle of hostility:

I'm sat with Sally, Anne, and one of Anne's work colleagues [...], a woman in her early 20s named Sarah and a mother to a three-year-old daughter. It's two weeks before the referendum and the three women are talking about the extended deadline in the registration system. Sally and Sarah had not registered. However both were planning to register today, and all three women were going to vote to leave the EU. Their discussion focussed on their being motivated to do this by the news that David Beckham was apparently urging people to vote remain, and they felt that this was "a liberty":

Anne "That fucking David Beckham can fuck right off, telling people to vote

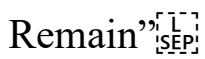

Sarah "What does he know about anything? When has he had to struggle to get his

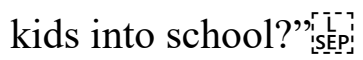

Sally "Yeah, him and Posh got no housing problems, apart from which one are they going to live in!"'i[s]p']

Sally and Sarah both registered their right to vote in the referendum that day, and later told me that they were excited about "getting their say". This was infectious; 
as other people came into the café the conversation got bigger and louder with more people joining. (p. 205)

Although David Beckham has well-known working-class origins, his pro-Remain stance was automatically interpreted as ignorance, being out of touch and condescendingly telling people what to do. What is striking, however, is that the women in McKenzie's vignette saw the news about Beckham as further motivation to go out and vote for Brexit. This suggests that in their view, Beckham's pro-Remain stance amounted to an attack on them on behalf of the elite, and this needed to be countered by 'kicking back' and voting to leave. This dynamic of perceived hostility and reciprocal retaliation was binding the community of Leave supporters as the conversation became 'infectious', bigger and louder.

Within such a polarised social and political field, the vision of overcoming injustice for Leave voters could mean nothing less than triumphing over their Remain-supporting counterparts. Effectively, this is a reversal of the hegemonic neo-liberal policies, cosmopolitan values and regimes of immigration that have defined UK policy over the past two decades. If people see themselves as unwillingly subjected to the order of things over the past two or three decades, then why not turn the tables? In fact, this is what it means to 'take back control', as the Leave campaign's slogan professed, within a socio-political landscape in which almost half of voters did not support Brexit.

Anger and ressentiment, however, should not be seen as specific to those who voted for Brexit. Rather, they pertain to both sides of the divide. As Insa Koch (2017) observes, '[i]n the lead-up to the referendum [...] anger was a central part of campaigns in favor of leaving [...]. Now, in its aftermath, anger is expressed by voters from the opposing camp, Remain, who struggle to accept the referendum result' (p. 226). One of the reasons for this lack of acceptance is that many Remain supporters fail to see exactly how leaving the EU would solve the issues 
related to schools, housing, jobs and public services that have been created by growing inequality and Tory policies of crushing austerity. Even if Remainers accept that Brexit was motivated by a declining quality of life that fully justifies anger towards the political elite, none of them can quite figure out how leaving will improve people's circumstances. This is why Remainers see Leavers as victims of a political fraud. Furthermore, many people associate Brexit's political landscape with xenophobia and racism on the basis of strong anti-immigrant rhetoric by the pro-Brexit campaigns, reduction of immigration as a major political demand of Leave voters and an increase in racist harassment and violence after the referendum. Brexit has consequently made many Remainers anxious about the future of the economy, as well as the threat of racism and the collective values of the country they live in. This has led to a widespread view of Leave supporters as 'bigots' and 'racists' in addition to 'turkeys who voted for Christmas'. The problem, however, is that Remainers - much like Leave supporters - also end up foreclosing dialogue through their anger-fuelled stereotypes and hostility towards Brexit. By keeping the focus on the alleged ignorance and racism of Leave voters, Remainers distract from the issues of declining quality of life, which only fuels the resentment of those on the receiving end of the accusations (see McKenzie, 2017, p. 205).

\section{Discourse, Fantasy, Nationalism}

The affective dimension of the Brexit deadlock, however, does not cover the whole story. Political discourse also matters, not just because it provides the materials and ideas for identity formation, but also because it brings into being particular modes of subjecthood based on imagined relationship to others who may or may not be physically encountered in daily life. Addressing the discursive or symbolic dimension of subjectivity has both methodological and analytical implications for understanding political agency. In terms of methodology, it is crucial to emphasise that circulations of affect related to political matters operate on a 
completely different scale from that of the face to face encounters between analyst and analysand or parent and child as described in most psychoanalytic writing. The difference is that within political life the figure of the other is often imagined in and through its discursive constructions - it is not known through face to face encounters, but rather through representations about others elsewhere in media outlets, online posts and stories told in pubs, cafes and workplaces (see Anderson, 1983; Moore, 2011; Mintchev and Moore, 2019). Discourses and narratives about others enable the subject to experience itself as part of a large network of actors - some of them similar to oneself, others radically different - whose actions ultimately lead to locally experienced consequences. Circulations of discourse can thus organise and structure the circulations of affect described above, but in doing so they can also extend the subject's affective ties to distant places and unknown others, going beyond the affective dynamics of the here-and-now that characterise the classical psychoanalytic encounter.

A second point about the intersection of affective and discursive elements of subjectivity concerns the way in which we theorise the relationship between language, fantasy and enjoyment (jouissance). This point has been emphasised by much of the writing within the Lacanian/post-Lacanian theoretical paradigm. A Kleinian object-relational approach can help us understand how affect gets short circuited, but it says little about the crucial dimension of enjoyment derived from specific modes of being in the world. This dimension is significant because it often underpins regimes of inequality through attachments to social scripts about injustice. As Wendy Brown (1993) points out in her analysis of ressentiment, the subject who has been injured by historical injustice can become invested in its injury and the cycles of reproach that the injury enables. Brown's argument was developed in the 1990s with reference to those excluded on the basis of ethnicity, race, gender and sexuality, but the new form of 
schism between those who thrive in a cosmopolitan setting and those who do not gives the argument renewed relevance. According to Brown,

identity structured by ressentiment [...] becomes invested in its own subjection. This investment lies not only in its discovery of a site of blame for its hurt will, not only in its acquisition of recognition through its history of subjection (a recognition predicated on injury, now righteously revalued), but also in the satisfactions of revenge that ceaselessly reenact even as they redistribute the injuries of marginalization and subordination in a liberal discursive order. ( $\mathrm{p}$. 403)

Brown does not explicitly reference Lacan here, but her description of ressentiment resonates with Lacanian theory, most notably in its reference to repetition or 'ceaseless reenactment' as a means of attaining satisfaction.

One of the key theoretical pillars of Lacanian psychoanalysis is the notion that the object of desire is a fantasy object that appears real, but that is in fact elusive - an object that can never be grasped or attained in the way in which it is imagined (see Žižek, 1989, pp. 87130; Mintchev, 2018, pp. 239-242). The impossibility of attaining the object of desire means that the subject is destined to a constant struggle - invariably ending in failure - to attain the object, and also to attain the enjoyment that comes with it.

But here we have a twist in the Lacanian plot of fantasy and enjoyment: what really gives the subject its enjoyment is not the (impossible) attainment of an elusive object, but rather the repetitive process - the 'ceaseless reenactment' - of trying to attain it (Žižek, 1991, p. 5). This reenactment, we argue, has important psychic and social consequences because it reproduces the affective structures of identity, difference and belonging. As Wendy Brown suggests in the passage quoted, injury and injustice can become the basis for recognition. A 
reenactment or reiteration of a subject position based on injury is then a way of affirming one's belonging to a group by seeking recognition both within and outside the group.

The subject's ceaseless repetition, furthermore, sustains its sense of purpose - its reason for being in the world - by enabling it to continue its quest for the desired object. As Lauren Berlant $(2006,2011)$ shows in her writing on 'cruel optimism', the subject can become unconsciously attached to certain forms of thwarted identity, and this enables it to keep pursuing its desires and aspirations. The problem, however, is that if the subject somehow overcomes the thwarting - for example, by getting what he or she wishes for and not knowing what to do with it - then the attachment to that particular mode of subjectivity can be lost as well. Such loss in turn opens up the danger of yet another, more radical thwarting, which leaves the subject incapable of relating to the world and to others. If this happens, then the subject has to look for ways to adapt to the new situation, and it may or may not succeed in doing so. Repetition or reenactment is thus a way of sustaining one's identity and its affective underpinning, while avoiding the difficult fact that having one's desire realised is never as fulfilling as it is initially imagined.

This theoretical model of fantasy and enjoyment has important implications for how we understand identity and nationalism in the context of Brexit, as well as the divisiveness and ressentiment that characterise today's relationship between 'nationals' and 'cosmopolitans'. As a number of Lacanian theorists have argued, nationalist politics and discourses often evoke a fantasy structure in which the nation-state appears as a lost object that needs to be recovered (e.g. Salecl, 1992; Stavrakakis and Chrysoloras, 2006; Žižek, 1993, 200-238). The experience of loss in turn serves to foreground the threat of others - immigrants, minorities, refugees, urban cosmopolitans, the political establishment, etc. - who are seen as 'stealing the enjoyment' of the national subject by taking its jobs, threatening its culture, undermining its welfare system and killing its community life (for a detailed examination of how racism and 
nationalism link to the 'theft of enjoyment', see Hook, 2018). The problem with a nationalism based on threat and sabotage, however, is that the fantasy of the nation as a great entity is unattainable in reality and so the image of the great nation can only be sustained on condition that there is someone preventing its realisation. Without this imagined thwarting, the fantasy will be exposed as an impossibility. Put simply, the nationalist subject needs its other as the very condition for maintaining its nationalist aspirations without coming to terms with its own shortcomings (see Hage, 1996).

Fantasies of national identity, however, are not always about exclusion and xenophobia as a means of recovering a lost greatness. They can equally be about a 'cosmopolitan' affirmation of multicultural difference and celebration of ethnic and cultural diversity (Moore, 2013). Within the UK, this ethics of difference is a major part of urban life, especially in large multicultural cities. In London, for example, the value of cultural diversity is often emphasised in policy documents and statements from the Mayor's office (e.g. Greater London Authority, 2018), but in addition to this, many Londoners, including white Britons, see the city's diversity as a public good (Mintchev and Moore, 2018, pp. 124-125, 2019). Yet, much like the nationalist subject position described above, the cosmopolitan subject position has its own fantasy structure, with specific forms of enjoyment, and ways of defining itself against a constitutive other. Affirming one's identity as a middle-class urban cosmopolitan involves fashioning oneself in the image of an open-minded and tolerant citizen, while refuting the other who is associated with narrow-minded racism, ignorance and stupidity. The constitutive other of the cosmopolitan subject is thus not the migrant/minority, but the other who is perceived as unwilling or unable to accept, appreciate the value of and conform to a culturally diverse and 'outward-looking' social order. This other is the one whose beliefs and values are seen as posing a challenge to the good life, while at the same time allowing the subject to establish its sense of self-worth through pejorative differentiation. 
The fact that Remain supporters attribute Brexit to racism, in addition to ignorance, is indicative of how this cosmopolitan enjoyment is generated. As Pierre-André Taguieff (2001, pp. 13-14) argued, the concept of racism is inherently adversarial - it implies not only a moral failure, but also a sort of emotional dysfunction which causes the racist to misconceive the truth of objective reality (the racist fails to see that racism is false because emotional dysfunctionality clouds his or her perception). In the case of Brexit, this 'truth' is the idea that diversity is a good thing and that immigration from the EU has made a positive contribution to the UK and its economy (e.g. Dustmann and Frattini, 2013; Dorling, 2016; Dorling and Tomlinson, 2019). As Taguieff shows, however, accusing the other of racism, and associating him or her with moral failure and a misconception of reality, has implications not only for the racist, but also for the anti-racist. It presents anti-racism as occupying a moral high ground and a position of epistemic objectivity. Similarly, when Remainers accuse Leavers of racism and ignorance they present themselves as both 'good' and 'right' in the same way that Leavers do when they decry the loss of the nation that has resulted from immigration and the selfishness of the elite. In both cases, repetition and reenactment of one's position is essential for affirming one's own value and sustaining a sense of stable subjectivity in relation to others.

\section{Conclusion}

Research in sociology, anthropology and politics has demonstrated that the outcome of the referendum was driven by a number of factors including political disaffection, real and perceived perceptions of decline, and anxiety about immigration. But addressing the economic, social and political dynamics of the Brexit divide does not offer a sufficient understanding of why people are so persistently attached to divisive political ideas, with little prospect for reaching a compromise or a consensus. Support for Leave and Remain has continued to be split since the referendum, and while a very small minority of voters have had a change of mind, 
the majority of the public remains committed to its initial decision in the referendum (BurnMurdoch, 2018). Approaching Brexit through a psychoanalytic lens draws attention to the ways in which affective relationships to others and the fantasies that structure and organise these relationships have locked people into two oppositional groups, each with its own ideas about what is right for themselves and for the UK as a whole. People are sticking to their commitments and arguing for Leave or Remain, not because the arguments for each side are convincing on their own terms, but because being right about leaving or remaining enables the structures of affect and fantasy to remain in place. The hypothetical scenario of realizing that one is wrong - regardless of whether he or she is a Remain or Leave supporter - would collapse the subject's affective organisation of identity, belonging and aspiration, thereby risking existential confusion and disarray.

At the time of writing, when the UK's future relationship to the EU is still uncertain, there is little hope that the country's polarisation will be adequately redressed. This is specifically the case if the UK ends up in a less favourable economic position than the one it currently holds as a member of the single market. In this scenario of economic decline, Remain supporters will blame Leavers for not listening to all of the doomsday predictions about economic collapse, while Brexit supporters will look for opportunists and saboteurs who are betraying the UK's sovereignty and prosperity. The divide will perpetuate itself because each side will blame the other for the negative outcome, while affirming the value of its own views. This is a dynamic of ressentiment, in which divergent fantasies of the good society generate cycles of mutual aggression and self-affirmation, with no possibility for productive dialogue.

To illustrate once again how this dynamic operates in practice, consider the following example from the media. In October 2016, following a fall in the value of the UK pound as a result of the Brexit vote, it was announced that the price of Marmite would be increased by the manufacturer (Unilever) in order to offset the losses resulting from the dip in currency value. 
This price increase was widely reported in the media, but it was interpreted in different ways that only confirmed the views and positions of pro-Leave and pro-Remain media sources. For example, the pro-Brexit Daily Mail published an opinion column entitled 'The great Marmite scam: Shame on Unilever for exploiting Brexit to hike prices' (Brummer, 2016). As this title makes clear, the culprit responsible for the change in price was the profiteering company that tried to opportunistically rip off the ordinary consumer, not the Brexit vote that has threatened to pull the country out of the European single market and made dozens of companies consider relocating away from the UK. However, a few days later, The Independent - a centre-left newspaper - published a piece with the following title: 'The Brexiteers' Marmite conspiracy theories exposed their utter ignorance of how markets really work' (Chu, 2016), a title that feeds into the stereotype of Leave supporters as uneducated and ignorant. The point is that each side on the Remain-Leave split subscribes to specific conceptions of itself, the other side and the meaning of Brexit through which they interpret the world. This means that the hostility between the two camps will likely persist in the future and almost certainly escalate in the case of economic decline.

Redressing this division in the future will require educational, economic and social policies that offer opportunities and decent livelihoods for all, and not just for the privileged few. However, it will also involve the difficult gesture of recognising and respecting the other's position even if the latter seems misguided, confused, or opportunistic. Anything less than that will only fuel the affective dynamics of ressentiment, causing people to reassert and strengthen their convictions about themselves and others. In a post-Brexit world of growing social divides, overcoming the rift between Remain and Leave supporters will be one of the biggest challenges to the country's ability to flourish and prosper, and people on both sides must think carefully about the consequences of continuing business as usual. 


\section{About the Authors}

Nikolay Mintchev is a research associate at the Institute for Global Prosperity at University College London. He specialises in the themes of ethnic identity and subjectivity in psychoanalysis and the social sciences. He is co-editor (with R.D. Hinshelwood) of The Feeling of Certainty: Psychosocial Perspectives on Identity and Difference (2017).

Henrietta L. Moore is the founder and director of the Institute for Global Prosperity at University College London, and Chair of Culture, Philosophy, and Design. She has written extensively on psychoanalysis, social transformation and politics. 


\section{References}

Anderson, B. (1983) Imagined Communities: Reflections on the Origin and Spread of Nationalism. London: Verso.

Ashcroft, M. (2016) How the United Kingdom voted on Thursday... and why. http://lordashcroftpolls.com/2016/06/how-the-united-kingdom-voted-and-why/, accessed 19 February 2017.

Balthazar, A.C. (2017) Made in Britain: Brexit, teacups, and the materiality of the nation. American Ethnologist 44(2): 220-224, doi: 10.1111/amet.12471.

Berlant, L. (2000) The subject of true feeling: Pain, privacy and politics. In: S. Ahmed, J. Kilby et al. (eds.) Transformations: Thinking Through Feminism. London: Routledge, pp. $31-47$.

Berlant, L. (2006) Cruel optimism. differences 17(3): 20-36.

Berlant, L (2011) Cruel Optimism. Durham: Duke University Press.

Berlant, L. and Greenwald, J. (2012) A conversation with Lauren Berlant. Qui Parle 20(2): $71-89$.

Biressi, A. and Nunn, H. (2013) Class and Contemporary British Culture. Basingstoke: Palgrave Macmillan.

Bourdieu, P. (1984) Distinction: A Social Critique of the Judgement of Taste. Translated by R. Nice. Cambridge, MA: Harvard University Press.

Braidotti, R. (1994) Nomadic Subjects: Embodiment and Sexual Difference in Contemporary Feminist Theory. New York: Columbia University Press.

Braidotti, R. (2011) Nomadic Theory: The Portable Rosi Braidotti. New York: Columbia University Press.

Brown, W. (1993) Wounded attachment. Political Theory 21(3): 390-410. 
Brummer, A. (2016) The Great Marmite Scam: Shame on Unilever for exploiting Brexit to hike prices. Daily Mail, 14 October. http://www.dailymail.co.uk/debate/article3837300/The-great-Marmite-scam-Shame-Unilever-exploiting-Brexit-hike-priceswrites-ALEX-BRUMMER.html, accessed 19 February 2017.

Burn-Murdoch, J. (2018) Are Britons changing their minds about Brexit? Financial Times, 1 October. https://www.ft.com/content/fd3582b6-c2f5-11e8-95b1-d36dfef1b89a, accessed 21 November 2018.

Butler, J. (1998) Moral sadism and doubting one's own love: Kleinian reflections on melancholia. In: J. Phillips and S. Lyndsey (eds.) Reading Melanie Klein. London: Routledge, pp. 179-189.

Butler, J. (2005) Giving an Account of Oneself. New York: Fordham University Press.

Chu, B. (2016) The Brexiteers' Marmite conspiracy theories exposed their utter ignorance of how markets really work. The Independent, 16 October.

http://www.independent.co.uk/voices/tesco-unilever-row-brexit-marmite-conspiracytheories-brexiteers-ignorance-how-markets-work-a7363946.html, accessed 19 February 2017.

Clarke, H., Goodwin, M. and Whiteley, P. (2017) Brexit: Why Britain Voted to Leave the European Union. Cambridge: Cambridge University Press.

Clarke, J. and Newman, J. (2017) 'People in this country have had enough of experts': Brexit and the paradoxes of populism. Critical Policy Studies 11(1): 101-116.

Delanty, G. (2017) A divided nation in a divided Europe: Emerging cleavages and the crisis of European integration. In: W. Outhwaite (ed.) Brexit: Sociological Perspectives. London: Anthem Press, pp. 111-123.

Deleuze, G. and Guattari, F. (2004) Anti-Oedipus. Translated by R. Hurley, M. Seem and H. Lane. London: Continuum. 
Dorling, D. (2016) Brexit: The decision of a divided country. BMJ (354): 1-2.

Dorling, D. and Tomlinson, S. (2019) Rule Britannia: Brexit and the End of Empire. London: Biteback Publishing.

Dustmann, C. and Frattini, T. (2013) The fiscal effects of immigration to the UK. Discussion Paper Series. London: Centre for Research \& Analysis of Migration, UCL. http://www.cream-migration.org/publ_uploads/CDP_22_13.pdf, accessed 8 April 2015.

Evans, G. (2017) Brexit Britain: Why we are all postindustrial now: Brexit Britain. American Ethnologist 44(2): 215-219, doi: 10.1111/amet.12470.

Ford, R. and Goodwin, M. (2014) Revolt on the Right: Explaining Support for the Radical Right in Britain. London: Routledge.

Frosh, S. (2018) Rethinking psychoanalysis in the psychosocial. Psychoanalysis, Culture \& Society 23(1): 5-14, doi: 10.1057/s41282-018-0072-5.

Gest, J. (2016) The New Minority: White Working Class Politics in an Age of Immigration and Inequality. New York: Oxford University Press.

Gest, J. (2018) The White Working Class. New York: Oxford University Press.

Goodwin, M. and Heath, O. (2016) The 2016 referendum, Brexit and the left behind: An aggregate-level analysis of the result. The Political Quarterly 87(3): 323-332.

Greater London Authority (2018) Inclusive London: the mayor's equality, diversity and inclusion strategy. London. https://www.london.gov.uk/sites/default/files/mayorsequality-diversity-inclusion-strategy.pdf, accessed 6 October 2018.

Hage, G. (1996) Nationalist anxiety or the fear of losing your other. Australian Journal of Anthropology 7(2): 121-140.

Hening, B. and Dorling, D. (2016) The EU referendum. Political Insight 7(2): 20-21.

Hinshelwood, R. (1991) A Dictionary of Kleinian Thought. London: Karnac. 
Hobolt, S. (2016) The Brexit vote: A divided nation, a divided continent. Journal of European Public Policy 23(9): 1259-1277.

Hook, D. (2018) Racism and jouissance: Evaluating the 'racism as (the theft of) enjoyment' hypothesis. Psychoanalysis, Culture \& Society 23(3): 244-266.

Klein, M. (1940) Mourning and its relation to manic-depressive states. In: The Work of Melanie Klein, Volume 1. London: Hogarth Press, pp. 344-369.

Klein, M. (1955) The psycho-analytic play technique: Its history and significance. In: The Work of Melanie Klein, Volume 3. London: Hogarth Press, pp. 122-140.

Koch, I. (2017) What's in a vote? Brexit beyond culture wars: Brexit beyond culture wars. American Ethnologist 44(2): 225-230, doi: 10.1111/amet.12472.

Kristeva, J. (2001) Melanie Klein. Translated by R. Guberman. New York: Columbia University Press.

Laplanche. J and Pontalis, J.-B. (1973) The Language of Psycho-Analysis. Translated by D. Nicholson-Smith. London: Hogarth Press.

Le Grand, E. (2015) Linking moralisation and class identity: The role of ressentiment and respectability in the social reaction to 'Chavs'. Sociological Research Online 20(4): 115, doi: $10.5153 /$ sro.3785.

Liberini, F., Oswald, A. et al. (2017) Was Brexit caused by the unhappy and the old? IZA Discussion Paper 11059. IZA Institute of Labour Economics. https://papers.ssrn.com/sol3/papers.cfm?abstract_id=3045756\#\#, accessed 20 September 2019.

McKenzie, L. (2017) 'It's not ideal': Reconsidering 'anger' and 'apathy' in the Brexit vote among an invisible working class. Competition \& Change 21(3): 199-210, doi: $10.1177 / 1024529417704134$. 
Mintchev, N. (2017) What is subjectivity and how can we study it empirically: Understanding the feeling of certainty through psychoanalysis and ethnography. In: N. Mintchev and R. Hinshelwood (eds.) The Feeling of Certainty: Psychosocial Perspectives. Basingstoke: Palgrave, pp. 31-47.

Mintchev, N. (2018) Object-relations and cultural narratives in the analysis of racism: Theorizing subjectivity after Klein and Lacan. Psychoanalytic Dialogues 28(2): 234-249, doi: $10.1080 / 10481885.2018 .1432959$

Mintchev, N. and Moore, H. (2018) Super-diversity and the prosperous society. European Journal of Social Theory 21(1): 117-134, doi: 10.1177/1368431016678629

Mintchev, N. and Moore. H. (2019) Migration and diversity. In: Y. Stavrakakis (ed.) The Routledge Handbook of Psychoanalytic Political Theory. Routledge: London, pp. 392404.

Moore, H. (2007) The Subject of Anthropology: Gender, Symbolism and Psychoanalysis. Cambridge, UK: Polity.

Moore, H. (2011) Still Life: Hopes, Desires and Satisfactions. Cambridge, UK: Polity.

Moore, H. (2013) Fantasies of cosmopolitanism. In: R. Braidotti, P. Hanafinand and B. Blaagaard (eds.) After Cosmopolitanism. London: Routledge, pp. 97-110.

Nietzsche, F. (1967) On the Genealogy of Morals. Translated by W. Kaufmann. New York: Vintage.

Popham, G. (2017) Brexit Britain: Ethnography of a rupture. MA Thesis. Utrecht University, Utrecht.

Pitcher, B. (2019) Racism and Brexit: Notes towards an antiracist populism. Ethnic and Racial Studies 42(14): 2490-2509, doi: 10.1080/01419870.2019.1623410.

Rose, J. (1993) Why War? - Psychoanalysis, Politics, and the Return to Melanie Klein. Cambridge: Blackwell. 
Salecl, R. (1992) Nationalism, anti-Semitism, and anti-feminism in Eastern Europe. New German Critique 57(Fall): 51-65.

Sedgwick, E.K. (2007) Melanie Klein and the difference affect makes. South Atlantic Quarterly 106(3): 625-642, doi: 10.1215/00382876-2007-020.

Skeggs, B. (1997) Formations of Class and Gender: Becoming Respectable. London: Sage.

Skeggs, B. (2004) Class, Self, Culture. London: Routledge.

Spinoza, B. (1996) Ethics. Translated by E. Curley. London: Penguin.

Stavrakakis, Y. and Chrysoloras, N. (2006) (I can't get no) enjoyment: Lacanian theory and the analysis of nationalism. Psychoanalysis, Culture \& Society 11(2): 144-163.

Taguieff, P.-A. (2001) The Force of Prejudice: On Racism and Its Doubles. Translated by H. Melehy. Minneapolis: University of Minnesota Press.

Thorleifsson, C. (2016) From coal to Ukip: the struggle over identity in post-industrial Doncaster. History and Anthropology 27(5): 555-568.

Virdee, S. and McGeever, B. (2018) Racism, crisis, Brexit. Ethnic and Racial Studies 41(10): 1802-1819. doi: 10.1080/01419870.2017.1361544.

Žižek, S. (1989) The Sublime Object of Ideology. London: Verso.

Žižek, S. (1991) Looking Awry: An Introduction to Jacques Lacan Through Popular Culture. Cambridge, MA: MIT Press.

Žižek, S. (1993) Tarrying with the Negative: Kant, Hegel, and the Critique of Ideology. Durham: Duke University Press. 